\title{
Positivization of Sharia Regional Regulations in North Sumatra
}

\author{
Irwansyah $^{1}$ \\ Faisar Ananda ${ }^{2}$ \\ Zulham $^{3}$
}

${ }^{1}$ Lecturer of Faculty of Sharia and Law, State Islamic University of North Sumatra, E-mail: alfaqih.iwan@gmail.com

${ }^{2}$ Graduate Lecturer of State Islamic University of North Sumatra, E-mail: faisarananda@uinsu.ac.id

${ }^{3}$ Lecturer of Faculty of Sharia and Law, State Islamic University of North Sumatra, E-mail: zulham@uinsu.ac.id

\section{Article Info}

Keywords:

Function;

Regulation, Region,

Nuanced, Shariah.

How to cite (APA Citation Style):

Irwansyah., Ananda, F., Zulham. (2021).

"Positivization of Sharia Regional Regulations in North Sumatra". Jambura Law Review. JALREV 3 Special Issue: 161-179

\begin{abstract}
The inability of the law to be an accommodating and acceptable rule makes for disharmony over diversity in Indonesia. Various sharianuanced regional regulations continue to emerge in various regional lines in Indonesia. However, it is necessary to conduct legal analysis related to its existence in the constitutional legal system in Indonesia. The research method used is normative juridical. The results showed that in a democratic country positivization of Islamic law both in absolute (law) and relatif (local regulations) does not violate in the constitutional legal system that also guarantees the fulfillment of human rights to its citizens. In addition, the lack of political will from the regional government of North Sumatra to support sharia-nuanced regional regulations proposed by districts / cities that are less responded to by the government at the provincial level that hinders the process of positivization of sharianuanced regional regulations in North Sumatra.
\end{abstract}

(C) 2021 - Irwansyah., Ananda, F., Zulham.

Under the license CC BY-SA 4.0 


\section{Introduction}

Indonesia as a legal country in addition to guaranteeing the fulfillment of human rights often experiences friction because of the many diversity that exist on the earth Indonesia. Various diversity sometimes needs to be harmonized so as not to occur disharmony. One of the steps taken by the government and local government is to issue sharia-nuanced regulations containing values as regulated by religion.

Using one of pancasila's main and priority principles, namely "God almighty", every citizen or community must practiceGod Almighty to carry out in the life of the nation. Every citizen must acknowledge the existence of his God and at the same time commit to practice the rules of his religion according to his beliefs with culture and mutual respect. To include moral divinity as the basis of the state, the state introduced a transcendent dimension in political life and combined the concepts of "sovereign God" and "sovereign people". Harmonization in the national legal system is directly related to the process of building harmony and balance in the substance of legislation. When viewed from the substance, the legislation / local regulations compiled by the authorized agencies must reflect the principles and rule of law applicable in the community, so that the laws that are drafted reflect the aspirations of citizens or local laws or regulations born from the aspirations of citizens can not be said elitist. Exclusive though sourced from the rule of religious law based on Islamic religious norms. Therefore, not all regulations in the field of law or regulation are derived from Islamic religious norms so that the establishment of positive legal regulations or products, exclusive / elite for Muslims only.

Deliberative democratic system that has been developed by the founders of the nation in an effort to find conformity between the philosophy of national and state life with religious understanding. Not putting the most votes first, but what is sought is a point in building togetherness and cooperation in various aspects. On reform reform, there are various regulations that provide opportunities to absorb regulations from national law, including local regulations. However, everything remains in the corridors of ideology' Pancasila and the 1945Constitution. Since the beginning of the entry of Islam in the archipelago, Islamic Sharia law has been applied and developed in the Indonesian Muslim community. But the so-called Islamic law in society still deviates from the discussion of fiqh, which is still a legal doctrine directed at the teachings of 
the imams. To practice the rules of Islamic law required legislation from the state, then this is where the ruler of political law plays a role. This will be directed to where the Islamic legal system in society that is still in the form of fiqh (legal beliefs) will be developed. ${ }^{1}$

Some sharia-nuanced regional regulations in North Sumatra such as (i) Medan City Regulation Number 10 of 2017 concerning Supervision and Guarantee of Halal and Hygienic Products, (ii) Medan City Regulation No. 5 of 2014 concerning Compulsory Learning of Madrasah Diniyah Takmiliyah Awaliyah, (iii) Tanjung Balai City Regulation No. 1 of 2015 concerning The Obligation to Read The Letter of the Qur'an for Muslim students of elementary, junior high and high school/vocational school, (iv) Tanjung Balai City Regulation Number 2 of 2015 concerning The Management of Zakat, Infak And Alms, (v) Asahan District Regulation.

\section{Problem Statement}

Acceptable law, must meet the needs and in accordance with the wishes of the community so that it can freely be obeyed and implemented and have a strong acceptance for the community. Addressing that diversity, there are many religiousbased regional regulations, in this legal study will be discussed about sharia-based regional regulations that exist in Indonesia if analyzed in the constitutional legal system in Indonesia.

\section{Method}

The method used in this study is empirical juridical law research method using legal systematic approach to review the existence of Sharia-based regional regulations in a positive legal order in Indonesia. Soerjono Soekanto explained that normative legal research is usually done by examining libraries and secondary data that includes research on legal principles, legal systematics, legal synchronization standards, legal history and legal comparisons. ${ }^{2}$ Meanwhile, Peter Mahmud Marzuki said the model of research approach in legal research includes statute approach, case approach, historical approach, comparative approach and conceptual approach (conseptual approach). ${ }^{3}$

\footnotetext{
Sirajuddin M, “Harmonisasi Norma Agama Islam Dalam Sistem Politik Hukum Di Indonesia,” Scientific Articles (n.d.): 5.

2 Soerjono Soekanto. (2012). Pengantar Penelitian Hukum. Jakarta: UI Press. p. 23

3 Peter Mahmud Marzuki. (2011). Penelitian Hukum. Jakarta: Kencana. p. 52
} 


\section{Discussion}

Efforts have been made to develop the Islamic legal system positively as one of the legal systems that recognize the existence and rights of life in Indonesia, since the establishment of the Islamic Kingdom in the archipelago, although in the previous period the legal book was positive for months and unification has not been systematically collected. The law is applied in the form of abstraction derived from the content of jurisprudence. In other developments, the trend of social change and national reality continues to show symptoms of disintegration of Islamic relations and local traditions. Thus, the social behavior of Muslims ranges from fundamentalists to assimilation, with respect to the role of elites in changing people's lives. The basis of the tendency can be seen in interpreting faith and social reality in the context of social relationships. This has long seemed extreme and at other times it has become open and tolerant. 4

The development of Islamic law has been going on for a long time, and gives many new nuances in the development of national law. However, Islamic law in particular has become an important part of the national legal system, which means that Islamic law has a significant impact on the direction of development of Indonesian law. The positive influence of Islamic law in the dynamics of the development of national law can be found in its implementation, which regulates all aspects of Indonesian people's lives. Thus, Islamic law plays a role in filling the legal void in positive law, and Islamic law is a source of value that contributes to the rules governed by positive laws. The application of Islamic law in Indonesia as a product of legislation is inseparable from the political formation that is taking place in the country, namely experiencing ups and downs. The characteristics of Islamic law always modify how Islamic law can formulate policies against the products of the law in accordance with the political developments in Indonesia. The formulation of the policy stipulated in the policy of legitimizing Islamic law is an effort to make the resulting legal results able to provide legal certainty to the community so that the direction of islamic law reform over time contributes

4 Bani Syarif Maula, (2003). Realitas Hukum Islam dalam Konfigurasi Sosial dan Politik di Indonesia: Perspektif Sosiologi Hukum Tentang Perkembangan Hukum Islam di Indonesia. Hermeneia: Jurnal Kajian Islam Interdisipliner, 2(2): p. 46. 
positively and in accordance with the people of Indonesia. ${ }^{5}$

The development of Islamic law has been going on for a long time, and gives many new nuances in the development of national law. However, Islamic law in particular has become an important part of the national legal system, which means that Islamic law has a significant impact on the direction of development of Indonesian law. The positive influence of Islamic law in the dynamics of the development of national law can be found in its implementation, which regulates all aspects of Indonesian people's lives. Thus, Islamic law plays a role in filling the legal void in positive law, and Islamic law is a source of value that contributes to the rules governed by positive laws. The application of Islamic law in Indonesia as a product of legislation is inseparable from the political formation that is taking place in the country, namely experiencing ups and downs. The characteristics of Islamic law always modify how Islamic law can formulate policies against the products of the law in accordance with the political developments in Indonesia. The formulation of the policy stipulated in the policy of legitimizing Islamic law is an effort to make the resulting legal results able to provide legal certainty to the community so that the direction of islamic law reform over time contributes positively and in accordance with the people of Indonesia. ${ }^{6}$

Efforts have been made to develop the Islamic legal system positively as one of the legal systems that recognize the existence and rights of life in Indonesia, since the establishment of the Islamic Kingdom in the archipelago, although in the previous period the legal book was positive for months and unification has not been systematically collected. The law is applied in the form of abstraction derived from the content of jurisprudence.260 In other developments, the tendency of social change and national reality continues to show symptoms of disintegration of Islamic relations and local traditions. Thus, the social behavior of Muslims ranges from students from fundamentalists to assimilation, with respect to the role of elites in changing people's lives. The basis of the tendency can be seen in elite students who interpret faith and social reality in the context of social relationships. This has long seemed extreme and

5 Suci Ramadhan, (2020). Islamic Law, Politics And Legislation: Development Of Islamic Law Reform In Political Legislation Of Indonesia. ADHKI: Journal of Islamic Family Law, 2(1): p. 75.

6 Ibid. 
at other times it has become open and tolerant. ${ }^{7}$

Changing the values of Islamic law is the constitutional obligation of the state to establish a national legal system in Indonesia obtained from three legal sources: customary law, positive law (Netherlands) and Islamic law. The third subsystem of this Law is the Law of Public Life and the Nation of Indonesia based on the Constitution of the State of Ter-Sermin at the opening of the 1945 Constitution. Article 29 of the 1945 Constitution stipulates that Indonesia is not a religious country, but that Indonesia is a religious republic and a country that recognizes the official religion, Islam. Catholics, Protestants, Hindus and Buddhists, are not secular countries. In the context of political law, the State must lift the values of religious law that are officially recognized by the State - when religion has a legal system, and establish a national legal system in Indonesia through constitutional mechanisms. ${ }^{8}$

In the view of Western thought, the law has previously touched on the theological methods used by believers, especially in the Middle Ages since the birth of hugo de Groot's theory of natural law. For example, Thomas Aquinas's theological approach says that the source of the supreme law is God, and then the law is divided into four categories: eternal law, natural law, positive law, and God's law. Thomas Aquinas says that the laws of nature are inseparable from the nature of God, even if it has to do with the proportion of people who think about God's creation. Does God's law fill the voidness of the human mind and lead man in ways that may not be wrong to go to the hereafter? God's law is found in the Bible. According to Alosius, the law of nature comes from God, both of whom recognize the source of the law coming from God. In contrast to Hugo de Groot, who said that all the provisions were right and good for him and could not be wrong with him. ${ }^{9}$

Various rules in Islam are based on the Qur'an and sunnah, and then on positive rights so that it becomes one of the positive laws that apply in Indonesia and also has the power to enforce it with a positive legal mediator, but only for the existence of the

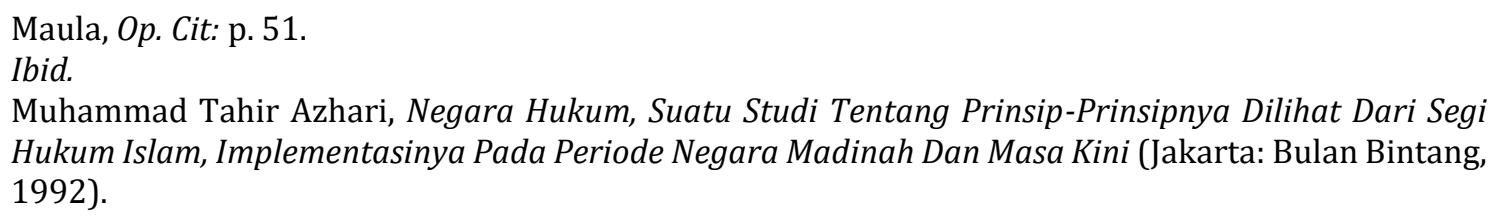


Muslim community. For example, related to Hajj, zakat, etc. There are many sharia or Islamic regulations that do not only apply in Aceh province as a special region that applies Islamic law through the absence of territorial differences between the two laws or perdasyariah. Not far from our area for example in North Sumatra, there are some areas that are not regional facilities but there are healthy regional regulations. Referring to the theory of rules principles relating to common interests, this can be achieved because it is contrary to the strict regime of the State of Indonesia, which also recognizes the existence of Islamic law. Because there are no standard rules that require the application of Islamiclaw.

\subsection{The Existence of Sharia Regional Regulations in the Local Government System in Indonesia}

The status of Islamic law in national law has been recognized and has an important role in the development of law. Islamic law is the raw material for the development of national law as well as customary law and colonial heritage law. The law then becomes a national law, which can win competition in the process of making it. Based on current developments, it can be assessed among the three legal systems in Indonesia that in the future Islamic law tends to provide input for the development of national law. In addition, because the majority of Indonesian Muslims and emotional affinity with Islamic law is also because the Western legal system has not really developed since Indonesia's independence. At the same time, customary law also shows a significant contribution to the development of national law. Therefore, the main hope for the development of national law is the contribution of Islamic law. ${ }^{10}$

Sharia-based laws and regulations are the basis of written law established by state officials / authorized institutions based on the content of material based on the principles of Islamic law to regulate aspects of life or the interests of believers. ${ }^{11}$

Islamic law can be seen before the independence of two periods: the acceptance of Islamic law is called a fully accepted teaching in Complexu, and the acceptance of

10 Masruhan, (2011). Positivisasi Hukum Islam di Indonesia Era Reformasi. ISLAMICA: Jurnal Studi Keislaman, 6(1): p. 131.

11 Encik Muhammad Fauzan Nur Chanifah Saraswati, (2019). Konstitusionalitas Peraturan PerundangUndangan Berbasis Syariah Di Indonesia. Simposium Hukum Indonesia, 1(1): p. 498. 
Islamic law is referred to under the customary law of ship theory. Islamic law is passed through two phases. The first stage, Islamic law as a convincing source in the context of the strict laws of the state, namely the source of the new law is acceptable if reliable. The second phase, the new Islamic law, became the official source in the country when the historic moment of July 5, 1959 approved the Jakarta Charter to activate the 1945 Constitution. ${ }^{12}$

Islam explains how one's attitude comes, including where he will return. Religion better identifies differences in the arteries of human life, such as the relationship between child and parent, the relationship between women and men through marriage, inheritance law, trade, etc., including the situation of government and state better with details that are the basic principles of Islam on which monotheism is based. Man must maintain and maintain his relationship with God, man, with his environment. ${ }^{13}$

Sharia-based laws have grown significantly in Aceh compared to provinces or provinces in Indonesia. From the description of the type of sharia-based legislation mentioned above, the reason or background of making legislation based on the provisions of Article 24C of the 1945 NRI Constitution if considered by all parties what is based on sharia legislation. The government's policy of "eliminating the "state of the land" is a fundamental right of the state.

Various types of sharia-based laws from the establishment, enforcement and implementation of laws, which often cause problems are Islamic law. This can be seen from the application of the Penal Code in Aceh, which also applies Islamic law to nonMuslims. "The enactment of the Penal Code in this law applies to all Muslims, namely clerics, non-Muslims and business entities engaged in business in Aceh," he said in Aceh Law No. 6 of 2014 on criminal code in Article 5. Qanun's energy if reflected on the Aceh region in this case, sharia principles against non-Muslims, do not pay attention to the principle of neutrality, which reflects harmony between the interests of individuals and society. From the theory of the four imams who break Islamic law is the layer of the

12 Muhsin Aseri, (2018). Politik Hukum Islam di Indonesia. Al Qalam: Jurnal Ilmiah Keagamaan dan Kemasyarakatan: p. 158.

13 Azhari, (3003) Negara Hukum, Suatu Studi Tentang Prinsip-Prinsipnya Dilihat Dari Segi Hukum Islam, Implementasinya Pada Periode Negara Madinah Dan Masa Kini. 
Qur'an, hadith or Sunna, and ijtihad.

The concept of sharia itself is the origin of the Islamic legal era, because the fundamental aspect of Shariah is one aspect of life or values. The meaning of sharia is similar to what is contained in the Qur'an, and there are values of life that justify this so that Muslims can seek guidance to guide the right path and gain benefits, prosperity and happiness.

Pospeta stated that the implementation of sharia-based laws is one of the country's steps in meeting the needs of Muslim citizens. This effort is added to the implementation of the mandate of "human rights" enshrined in the Constitution, but is also an effort to achieve justice for the Indonesian nation. The realization of shariabased law is not only the effect of Islamic tradition, because the formation of laws is also an encouragement for community participation. The government's policy of "reducing the number of people who have experienced such practices is not the same as that of the United States."

Another way to interpret the third element of the legal system is: (a) the structure is fed as a machine; (b) illegal feedstructure; and (c) feed structure on the system. (b) Substase is what the machine makes and manufactures; (c) legal culture is everything or anyone who decides to turn it on and off, and decides how to use the device. ${ }^{14}$

The first current can be called formal /scriptturalistic. The term is intended to refer to the forms of thought of those who advocate the strict application of the formal form of Islam. The political orientation of formalism suggests on the one hand that cultural Islam should be politicized, which then places islamic symbolism. Maintaining a formality on the validity of the language of revelation is not only to show a strong connection with traditional evidence, but also to preserve the fundamentalist tendency to emphasize the concept of the Islamic Bible, albeit without at the same time conforming to modern institutional forms and ideas. Islamic formalities seem to include a literal interpretation of the Bible. The focus itself is the traditional text on the one hand, and on the other hand emphasizes the fundamentalist tendency to emphasize the biblical concept of Islam, but not in the conceptual sense - a concept of

14 Hasan Basri, (2011). Kedudukan Syariat Islam di Aceh dalam Sistem Hukum Indonesia. Kanun Jurnal Ilmu Hukum, 13(3): p. 79. 
sharia that can be understood by the traditional. However, it does not correspond to modern forms of ideas and institutions. ${ }^{15}$

The term fundamentalism first coined by Christians in the United States refers to a tradition of religious thought that tends to interpret religious texts strictly and literally. This text derives from the assumption that modernity, which tends to interpret religious texts flexibly to adapt them to various developments in modern times, ultimately brings religion to an increasingly repressed position on the sidelines. It also demonstrates a fundamentalist Protestant tendency to interpret religious texts among 20th-century Muslims. ${ }^{16}$

While the central government theoretically holds power in religious affairs under a decentralized law adopted in 1998, it also gives local governments the power to change national laws through local regulations. Provincial and provincial governments have used their new authority to adopt local regulations on a variety of ethical and religious issues. For example, some of these local regulations prohibit alcohol consumption, gambling, and prostitution. Others organize a group of religious charities, teach reading the Qur'an, and dress for women. Most scholars agree that the application of this legal system "is clearly a historic breakthrough in the Islamic political process in Indonesia". While sensational reports claim that the most involved political environment after 1998 has sparked widespread "political Islamization" and "creeping laws"in the archipelago, more accurate assessments show significant time differences and silver in sharia application. Some experts claim that the adoption of the Islamic legal system has slowed with further consolidation of democracy in Indonesia. ${ }^{17}$

Compared to Malaysia, Islam became the country's official religion, so the country has a special obligation to protect Islam and Muslims, which in turn leads to discrimination against religion. There are other types that are more acute in Pakistan, which is a constitutional Islamic state, but the division between Muslims in Pakistan is more complex among various moderate groups. Sunnis with a hard line between Sunnis and

15 Efrinaldi, (2014). Perda Syariah Dalam Perspektif Politik Islam Dan Religiusitas Umat Di Indonesia. Madania: Jurnal Kajian Keislaman, 18(2): p. 124.

16 Abuddin Nata, (2001). Peta Keragaman Pemikiran Islam Di Indonesia (Jakarta: PT RajaGrafindo Persada. p. 122

17 Dani Muhtada Michael Buehler, (2016). Democratization and the diffusion of shari'a law: Comparative insights from Indonesia. South East Asia Research, 24(2): p. 263. 
Shiites, between Muslims who migrated from India during the partition of 1947 and Pakistan, and between rich and poor. On the other hand, countries such as India, China, Singapore and Thailand that use certain religions as official religions do not declare them secular, but there are religious groups that have significant influence and an important role in the political, social and cultural arena. ${ }^{18}$

On the basis that human affairs are not only with man, but the social life of his neighbors is not only between two but between three, namely between man and man and His God and thus judging from his legal agenda, legal policy is in line with the common goal. The law must exist in its basic form as law, namely ensuring fair regulation, providing legal certainty and sharing of benefits. It distinguishes legal policy from other political issues (e.g. economics, culture, etc.). The ideal values inherent in law (fairness, certainty and utility) form the basis and turning point of legal policy. For legal reasons is dedication to the public interest, all elements of the law such as fairness, certainty and interest - are public instruments of public service or common interest. Here, idealism is rooted in legal policy. The main function of legal policy is to provide the basis for dedication and common interests.

Islamic law during the transition period, the old regime, and the new regime were slow because the current political system was not open to the establishment of religious law as the basis for the product of legal law. The government's policy on "social and economic development" is to provide a more effective and effective system for the development of the labor market. Therefore, law policy in the reform era shows a different political face from the old and new regimes in seeing the reality of legal pluralism developing first and foremost in terms of the opportunities and challenges that occur with Islamic law. Today's political establishment is democratic because it increases people's chances of identifying. The direction of state policy. Politically, Indonesia provides a happy space and opportunity for the movement and development of Islamic law in the dynamics of political and ambitious interactions between Islamic political parties, scholars, public figures, state officials and scholars, including the political efforts of Islamic sharia legislation in Indonesia. Currently, we can see the development of parties in Indonesia with Islamic authorities who have jointly 
established Islamic law as a source of national law through the legislative realm. The political system in Indonesia shows that although Islamic political aspirations do not dominate, the view of political composition provides ample opportunity for the development of Islamic law in Indonesia in the form of national legal products with Islamic authorities. ${ }^{19}$

The provisions of the legal standards in this law provide legitimacy to formalize Islamic law, which is transformatively integrated into the political and legal system of the Indonesian state. The assimilation of Islamic law into laws and regulations at the regional level opens the door to the spirit of autonomy granted by regional and private groups (in this case regional autonomy). The evidence is then contained in the provisions of paragraph 1, article 18B23, explaining that "the State recognizes and respects special units or special local governments governed by law". In this case, Aceh gained legitimacy to implement Islamic law through local regulations guaranteed by Law No. 11 of 2006 concerning the Government of Aceh. ${ }^{20}$

If the local government is formed on the basis of the above authority, based on the procedures that have been developed, most (articles) are not contrary to the laws and/or public interests mentioned above, then the actions of the government. Conversely, if one or all three elements are not met, the government's actions are legally flawed or illegal. If the element that has not been achieved is the element of authority, it is known as the term disability authority, if the unrealized is the element of action, what the defect is, if the element that has not been achieved is the element of substance, it is known as the defect of the substance. Therefore, these three elements can be used as indicators to assess the validity of government actions, including the validity of local regulations. Talk about the validity of the law is very closely related to the principle of legitimacy, as one of the criteria of the concept of Rechtsstaate. As for the principle of legitimacy, Sri Muliani cites the opinion of Philippus M. Hadjon, whose opinion is not in line with Burkin and others. This is every action that the government

19 Ramadhan, (2020). Islamic Law, Politics And Legislation: Development Of Islamic Law Reform In Political Legislation Of Indonesia. ADHKI: Journal of Islamic Family Law, 2(1): p. 63-76

20 Ummu Salamah \& Reinaldo Rianto, (2018). Perda Syariah Dalam Otonomi Daerah. Mizan: Journal of Islamic Law, 2(2): p. 252-253. 
has to be under the law. ${ }^{21}$

Sharia-based law enforcement can be seen from the perspective of legislation. In this context, it also refers to the level of Kelsen's legal theory (Stofenbau's rule of law/theory hierarchy) which aims to assess legal certainty with respect to law enforcement, since legal certainty is determined by the validity of the law or its suitability in the legal hierarchy. In addition, it also aims to analyze the interconnection between the states of law that refers to fundamental philosophical values to feel justice and truth, and social values in accordance with the prevailing cultural values in society. On this basis, the rules will result in a coherent legal system, so that disputes between rules are subject to the same rules. For example the posteriori legal principle of repealing domestic law or the principle of supreme law repealing a lower law if a higher-level rule to back away from the lower-level rule. The basic nature that accompanies these basic rules is consistency and the principle of legitimacy.

Islamic-normative theology is one method of understanding Islam that most fathers compare to understanding other similarities because they are often at odds with the spirit in Islamic history embraced by society more broadly. 22

It is clear that Islam covers a much wider scope than the concept of Western law, while Islamic law also includes decency. The convergence of legal and ethical relations in Islam is reflected in the founding theories of Islamic law, such as Imam Shafi'i, which states that there are five types of rules, namely halal, advice, humiliation, mandatory, and haram. In Islamic law, morality is inseparable, because the concept of Western hazarin applies to, he says, that talking about the law without being simple with me learns to grow crops regardless of the soil. Islamic law is not only for the time being but also in Western concepts, because Islamic law has two characteristics that have been attached to it since the birth of Islam, namely the nature of secularism and religion in accordance with islamic principles. Man always remembers the happiness of the world during his life, when he sided with happiness in the afterlife after death. ${ }^{23}$

21 Abdul Hadi, (2014). Study Analisis Keabsahan Perda Syariat Dalam Prespektif Teori Hirarki Norma Hukum. Ummul Qura, 4(2): p. 58.

22 Abudddin Nata. (2001). Peta keragaman pemikiran Islam di Indonesia. Divisi Buku Perguruan Tinggi, RajaGrafindo Persada.

23 Azhari, Op., Cit. p. 67 
Prior to the entry of positius, experts believed that this Western country used a rational approach that began with the flow of nature. The place of absolute release of religious law as a result of the rationality of the seventeenth century and the "Oviklarong of the 18th century" which was not recognized by the robot king Devin and ceded the legal authority of the gospel because God was excluded from the field of law because he considered that the law was independent and all laws were human law. Then since Jeremy Bentham brought the positivity flow, the color of thought about the law began in the West because whether the law depends on the feasibility of people's values but people should be subject to the law and therefore the size of the law lies in its usefulness although it must be contrary to the morals that still have binding power over this law which means that it occupies a higher moral position. ${ }^{24}$

The opportunity and means of islamic legal status is to introduce Islamic values into the law and not in any way. To immediately make your own laws a great opportunity is the status of Islamic law over any written law, from the basic law to the lower law. This model is beyond the normative approach to making Islamic law under certain laws. But at the same time it will have a wider scope, because it will be able to cover many aspects, types of legislation or legislation. Aimli says, but in practice the law is not inclined, the current line of Islamic law has been absorbed in several areas of law. In other countries, the number of women in the country is increasing. The development of Islamic law in Indonesia tends to occur through two channels, legislative and nonlegislative. The tendency to build laws outside the law is more than just a legal method, due to structural and cultural constraints, both internal and external. ${ }^{25}$

The relationship between religion, state and law is then associated with the concept of religion in the Qur'an, which basically has two dimensions: religion, spiritual and social good. Man as the penerus organizer of the earth and the human environment can behave well in carrying out his relationship with God and with his fellow human beings in society or country or even the relationship between the state and the human relationship with its environment.

So for example because the catalyst from outside the ego and suprego moves as quickly

24 Ibid.

25 Masruhan, Op., Cit: p. 132 
as possible to fully master the energy. He who wins as much as possible is to win the battle and as a result you will be able to see someone's behavior. ${ }^{26}$

This country is no exception Indonesia, seen from the perspective of political religion, Islamic law and the State has always been an entity throughout the history of Indonesia, which has always involved conflicts and tensions in the position of religious relations (Islam) and the State, between the project of secularization and Islamization of the State and society. This tension occurs under two different important conditions. First, the country of study or theory is ideal. This debate arose in the late 1930s between Sukarno and Muhammad Natser.7 seconds, a state of proletarian realism or experimental ideology. The controversy occurred in the preparation of the fundamentals of indonesia's post-colonial constitution, which took place at a hearing of the investigative body, the Indonesian Independence Efforts, at a session of the Preparatory Commission for Independence. 18-22 August 1945, for the preparation and ratification of the 1945 Constitution. ${ }^{27}$

Islamic law in Indonesia is inseparable from the history of sharia or doctrinal development in Indonesia since the beginning of the spread of Islam in the archipelago in the 13th century, which is inseparable from the dynamics of Islamic thought elsewhere, especially Arab thought and its extensive relationship with a network of scholars living in Mecca and Medina from the 17th century until the end of his reign. ${ }^{28}$

Islamic law is a form of regional organization (province and province) established by local government agencies in which certain rules, souls, and provisions of Islamic law are instilled in the legal system at the regional level. It is a task of different interpretation of which parts to consider. Because each region, region or city has different problems and problems. ${ }^{29}$

The dynamics of the development of the legislation mentioned above seem to be in line with the development of regional autonomy, which allows local governments to

26 Hayatun Na'imah, (2016). Perda Berbasis Syari'ah Dalam Tinjauan Hukum Tata Negara. Khazanah: Jurnal Studi Islam dan Humaniora, 14(1): p. 100.

27 Ibid.

28 Sheikh Muhammad Husayn Fadlallah. (1995). Islam and the Logic of Power (Bandung: Mizan. p. 157

29 M. Zainal Anwar, (2018). Sharia Expression in Contemporary Indonesia: An Expansion from Politics to Economics. Ulumuna, 22(1): p. 100-101. 
regulate all regional affairs in local regulations. This is especially true for domestic regulations on local taxes and sanctions. On the other hand, there are locals who want to apply Islamic law in their area, which has sparked controversy.

Regional regulation (Perda) is a form of local government together in achieving peace and public order, protecting the community and the community stipulated in the provisions of local regulations in accordance with local regulations. Legal principles that grow and develop in society as long as it is not contrary to the principles of the unitary state of the Republic of Indonesia. The establishment of the Regulation must go through the stages of planning, drafting, discussion, decision making and ratification on the basis of the provisions of the legislation contained in Law No. 12 of 2011 on the Establishment of Legislation so that the regulation can be applied and implemented in public life. The regulation will not be able to if the will of the people absorbed by the House of Representatives for academic manuscripts does not guide the aspirations of the community and through the drafting of regional regulations through philosophical, sociological and juridical academictexts that can be limited.

The relationship of the central government with the local government in overseeing the implementation of the central government with the local government related to the supervision of the organization in order to strengthen the unitary state that adheres to the decentralization system. The oversight in this paper is not aimed at limiting the independence of the territory or limiting it to internal affairs, but the surveillance here avoids local government authorities from crossing the line and is considered "excessive", which is precisely an opportunity to dominate political interests. Bagir Manan also states that there is no autonomy without supervision or autonomy. This means that surveillance is a symbol of national unity that will balance decentralization and excessive centralization.

The application of sharia law in some areas such as Aceh has become the final authority of the central government as stipulated in the Local Government Law. However, there is still the possibility of organization in the field of Islamic law. That's because of the following. First, the relationship between the central government and the local government is in a position to achieve political decentralization, so that the local government has broad authority to develop regional policies so that their influence is 
blatantly contrary to the policies and policies of the central law. Second, there is still an opportunity for central government authorities to supervise regulations imposed during control mechanisms updated with Law No. 23/2014.

If we assume that the legal basis is the product of public policy, the wishes of the regional president, which is the dominant position in the local government environment, will certainly be very decisive in forming an organization. If regional leaders have a progressive religious view of people's prosperity, the resulting law is a hallmark of the response, which places the role of religion as a social force to improve people's living standards. Conversely, if regional leaders have rigid religious views and are more religiously oriented towards worship in a narrow sense, then when they solve moral problems in society, they must use the proper rules in Islamic law to formalize them through Shariah. It is used to achieve the goal of achieving a legal, orderly and fair society, although the rules of the game have absolutely nothing to do with the actual state of society. ${ }^{30}$

The three components of Islam are faith, law and morality. Akkads can be interpreted as a belief system of pure monotheism that exists only in Islam. Sharia k is a set of rules governing human behavior that includes two aspects of relationships, namely, human relationship with God is vertical relationship, human relationship with natural environment, horizontal or in laboratory (social). Morality is a set of moral values that is a moral system in Islam that is born of what a person must do and act in the implementation of his relationship with God and fellow living beings such as humans, animals, plants, etc. ${ }^{31}$

If the central government supports sharia law, it is certainly not repealed and considered constitutional, although it is considered discriminatory by some people. If this is not in keeping with the Government's political interests, the law of innocence is easily abolished. Of course, this authority has the power to abuse the government in terms of surveillance,so asnot to close the possibility that judges will violate, test and remove regulations solely for political purposes. Therefore, if sharia continues to be established in areas other than Aceh, the same path is the government's efforts to

30 Sulit Fuadatul Khilmi, (2018). "Menempatkan Perda Syariah Dalam Perspektif Hukum Tata Negara Pasca Reformasi," The Law of the Lanterns 5, no. 1(1): p. 46.

31 Azhari, Op. cit. p. 68 
politicize religion. Religion is used as a tool for political interests at the elite level. This, of course, justifies the fact that the rule of law is subject to political sovereignty. And in the perspective of constitutional law, there is no problem with the position of Shariabased regional regulations in Indonesia.

\section{Conclusion}

Referring to the theory of rules principles relating to common interests, this can be achieved because it is contrary to the strict regime of the State of Indonesia, which also recognizes the existence of Islamic law. Because there are no standard rules that require the application of Islamiclaw. In the perspective of constitutional law, there is no problem with the position of Sharia-based regional regulations in Indonesia. If the central government supports sharia law, it is certainly not repealed and considered constitutional, although it is considered discriminatory by some people but as long as there are diverse rules that do not cause national disintegration and are able to create legal observance in society then it is appropriate that various sharia-nuanced regional regulations in Indonesia should be supported from its formation to its implementation. The willingness of the local government to respond to local regulations nuanced sharia so as not to impede the process of positivization so that for the affairs of religious life that becomes the authority of the local government can be more aspirational and participatory.

\section{Reference}

Books:

Azhari, Muhammad Tahir. (1992). Negara Hukum, Suatu Studi Tentang PrinsipPrinsipnya Dilihat Dari Segi Hukum Islam, Implementasinya Pada Periode Negara Madinah Dan Masa Kini. Jakarta: Bulan Bintang.

Fadlallah, Sheikh Muhammad Husayn. (1995). Islam and the Logic of Power. Bandung: Mizan.

Marzuki, Peter Mahmud. (2011). Penelitian Hukum. Jakarta: Kencana.

Nata, Abuddin. (2001). Peta Keragaman Pemikiran Islam Di Indonesia. Jakarta: PT RajaGrafindo Persada.

Soekanto, Soerjono. (2012). Pengantar Penelitian Hukum. Jakarta: UI Press. 


\section{Journals:}

Anwar, M. Zainal. (2018). Sharia Expression in Contemporary Indonesia: An Expansion from Politics to Economics. Ulumuna, 22(1), 96-111.

Aseri, Muhsin. (2018). Politik Hukum Islam di Indonesia. Al Qalam: Jurnal Ilmiah Keagamaan dan Kemasyarakatan: 158.

Basri, Hasan. Kedudukan Syariat Islam di Aceh dalam Sistem Hukum Indonesia. Kanun Jurnal Ilmu Hukum, 13(3), 75-92.

Efrinaldi. (2014). Perda Syariah Dalam Perspektif Politik Islam Dan Religiusitas Umat Di Indonesia. Madania: Jurnal Kajian Keislaman, 18(2), 119-130.

Hadi, Abdul. (2014). Study Analisis Keabsahan Perda Syariat dalam Perspektif Teori Hirarki Norma Hukum. Jurnal Ummul Qura, 4(2). 58.

Khilmi, Sulit Fuadatul. (2018). “Menempatkan Perda Syariah Dalam Perspektif Hukum Tata Negara Pasca Reformasi." The Law of the Lanterns. 5(1): 46.

M, Sirajuddin. (2014). Harmonisasi Norma Agama Islam Dalam Sistem Politik Hukum Di Indonesia. Madania: Jurnal Kajian Keislaman, 18(2), 147-160.

Masruhan. (2011). Positivisasi Hukum Islam di Indonesia Era Reformasi. ISLAMICA: Jurnal Studi Keislaman, 6(1), 119-133.

Maula, Bani Syarif. (2003). Realitas Hukum Islam dalam Konfigurasi Sosial dan Politik di Indonesia: Perspektif Sosiologi Hukum Tentang Perkembangan Hukum Islam di Indonesia. Hermeneia: Jurnal Kajian Islam Interdisipliner, 2(2): 46.

Michael Buehler, Dani Muhtada. (2016). Democratization and the diffusion of shari'a law: Comparative insights from Indonesia. South East Asia Research, 24(2), 261282.

Na'imah, Hayatun. (2016). Perda Berbasis Syari'ah Dalam Tinjauan Hukum Tata Negara. Khazanah: Jurnal Studi Islam dan Humaniora, 14(1), 27-40.

Nur Chanifah Saraswati, Encik Muhammad Fauzan. (2019). Konstitusionalitas Peraturan Perundang-Undangan Berbasis Syariah Di Indonesia. Simposium Hukum Indonesia, 1(1), 496-510.

Ramadhan, Suci. (2020). Islamic Law, Politics and Legislation: Development Of Islamic Law Reform In Political Legislation Of Indonesia. ADHKI: Journal of Islamic Family Law, 2(1), 63-76.

Ummu Salamah \& Reinaldo Rianto. (2018). Perda Syariah Dalam Otonomi Daerah. Mizan: Journal of Islamic Law, 2(2): 252-253 